\title{
REFORMATION OF THE INSTITUTIONAL ANTI-CORRUPTION SYSTEM IN THE CONTEXT OF EUROPEAN INTEGRATION TRANSFORMATION
}

\author{
Aleksei Fedotov ${ }^{1}$, Maryna Voloshyna²
}

\begin{abstract}
Ukraine belongs to a group of countries in which political, grand, and petty corruption deeply rooted in various spheres of life and became an organic element of social relations. During 2014-2018, the fight against corruption in Ukraine was identified as one of the key priorities of the state policy. This was also noted by international organizations. The implemented reforms contributed to moving Ukraine from 144th place in 2013 to 130th place according to the Corruption Perception Index. The purpose of the article is determined as to study reforming of the institutional system of the fight against corruption in the context of European integration transformation directed to increasing transparency and openness of the state as an institute and improving the governance. Traditionally, three functional types of corruption are distinguished: political corruption, grand corruption, and petty corruption. The author presented a generalized group of indicators of measuring the efficiency of the fight against corruption, including: Group 1. Economic indicators: reduction of economic losses as a result of the elimination of specific corruption schemes and the elimination of conditions that give rise to corruption; Group 2. Indicators of the activity of the law-enforcement system: the number of persons brought to administrative and criminal responsibility for corruption violations and crimes; amounts of damages recovered; Group 3. Indicators of public acceptance of the effectiveness of counteraction to corruption: assessment of the dynamics of corruption in various dimensions by different social and professional groups. For successful application of the experience of EU countries when developing effective anti-corruption policy in Ukraine, it is necessary: firstly, determine and implement in Ukrainian legislation relevant international legal rules of state, regional, and local nature; secondly, given the successful experience of certain countries, identify a complex of most important for Ukraine factors aimed at providing effectiveness of state policy of preventing corruption, structure them based on principles of priority and the most functionality in order to create a model optimal for Ukrainian conditions; thirdly, develop and form for this model proper institutional support of regulatory character that would harmoniously combine state, regional, and local levels of public administration. The paper determines "direct" anti-corruption effects of corresponding changes in economic governance. It is obvious that direct effects can be levelled by corruption risks in related spheres. So, the delegation of certain powers and financial resources to the local level in the process of decentralization objectively restricts corruption in the relations of "centre-regions" in terms of the distribution and use of financial resources, however, without effective anti-corruption system at the local level, the anti-corruption effect of decentralization will be less than expected. In order to overcome mass violations of anti-corruption norms and rules, it is needed to implement a whole range of measures to criminalize corruption, that is, to establish criminal responsibility for corruption offenses and corruption-related offenses and create a law enforcement system capable of effectively counteracting the corruption actions that we have identified in the study.
\end{abstract}

Key words: corruption, shadow economy, anti-corruption policy, performance measurement of fight, anti-corruption measures.

JEL Classification: O17, F42, H11, D73, R10, K32

\footnotetext{
Corresponding author:

${ }^{1}$ National University “Odessa Law Academy”, Ukraine.

E-mail:fedotov_ap@ukr.net

${ }^{2}$ Kharkiv National University of Internal Affairs, Ukraine.

Dnipropetrovsk State University of Internal Affairs, Ukraine.

E-mail:m.voloshyna@gmail.com
} 


\section{Introduction}

Unfortunately, Ukraine belongs to a group of countries where political, grand, and petty corruption deeply rooted in various spheres of life and became an organic element of social relations. Corruption leads to losses of state and population as a result of ineffective use of budget funds, low quality of public services, and also increases the uncertainty of the environment in which economic agents and households operate. However, assessing this phenomenon in Ukraine, an impartial researcher faces problems since international ratings primarily measure corruption only, while economic assessments of the losses from corruption and, accordingly, the benefits of overcoming it are very lacking. During 2014-2018, the fight against corruption in Ukraine was identified as one of the key priorities of the state policy. Due to a number of successful measures, certain progress in overcoming corruption was also noted by international organizations. Implemented during these years reforms contributed to moving Ukraine from 144th place in 2013 to 130th place according to the Corruption Perception Index.

Two main lines of actions that reduce the level of corruption in the country can be generalized: the narrowing of opportunities for corruption due to reforms in various sectors and the creation of an effective system of institutions for fighting corruption. The article will consider the changes made in the first direction.

The purpose of the article is determined as to study reforming of the institutional anti-corruption system in the context of European integration transformation directed to increasing transparency and openness of the state as an institute and improving the governance.

At the same time, for the analysis, a limited number of anti-corruption measures have been selected, which have already given an economic effect in those areas where corruption has traditionally been considered a visiting card of Ukraine. All opinions and views expressed in the paper belong exclusively to its authors and do not necessarily reflect the official policy or position of the Government of Ukraine or any government agency or members of the International Editorial Board. The article is based on sources and data in which the given information is reliable on the date of release (Ukraine Against Corruption, 2018).

\section{The methodology of research}

Corruption and fight against this phenomenon is a complex and multidimensional process. Therefore, assessments of the scale of corruption, the willingness to fight it (political will), and the effectiveness of various anti-corruption measures vary greatly. Herewith, it should be noted that all known today international ratings measure precisely perception of corruption, while the scientific economic assessments of corruption losses and, accordingly, the benefits of overcoming it are obviously rare.
Measuring the scale of corruption and an adequate assessment of the effectiveness of anti-corruption measures are a challenge for experts, politicians, and society. But without such an analysis, it is impossible to measure the degree of success of the anti-corruption strategy and to adequately adjust the content, time, and mechanisms for implementing the appropriate steps.

Overcoming corruption becomes the main prerequisite for the successful European integration processes, at the same time, it should be pointed out that adoption of laws aimed at implementing the state anti-corruption policy and required for the successful European integration processes takes place due to the pressure on the authorities and politicians on the part of civil society. A formal approach to the process of fight against corruption indicates that dominant corruption factors in Ukraine become not only factors of materialeconomic but also ideological, moral nature, general and legal culture. Obvious inefficiency of measures applied in relation to corruption determines the expansion of the issues of research on corruption and mechanisms of its influence in various spheres of economics, sociology, law, and public administration.

Formation of state anti-corruption policy and definition of political corruption are investigated in works by Stepanova A. (2015), Kyrylenko O. (2015), Popok A., Reshota V. (2013), Rybak A. (2011), and others. European principles of good governance and reform of the system of executive authorities in Ukraine, as well as implementation of principles of good governance as a factor of activation of economic-political development of the state, were studied by Shevchuk B. (2012), Yameletsky O. (2012), Martynyuk O. (2015), Paweł Dziekański (2017). At the same time, the study of reformation of the institutional anti-corruption system in the context of European integration transformation is relevant and still insufficiently presented in domestic scientific publications.

Traditionally, three functional types of corruption are distinguished, namely:

political corruption. It is the manipulation of political decisions, rules, procedures, and activities of institutions in the area of resource allocation and financing by politicians abusing their authorities in order to preserve and enhance their power, status and wealth, and to obtain private gain;

grand corruption. It covers actions of senior officials in order to profit at the expense of society through distorting influence on state policy and mechanisms of state functioning at the central (national) level;

petty corruption. In this case, it is about the daily misuse of power by middle and low-level officials in the process of dealing with citizens in solving their (citizens') personal problems.

We have limited ourselves to analysing measures aimed at overcoming political corruption first of all. 
At the same time, we understand that the strategic goal is to create zero social tolerance for corruption at all levels.

In general, corruption and, accordingly, counteraction to this phenomenon is a complex and multidimensional process. Components of the formation of counteraction strategy in the field of political corruption are grouped in Figure 1. According to the content, all measures aimed at fighting corruption can be conditionally divided into two groups: a) detection of corrupt acts and punishment of the perpetrators, and b) elimination of the conditions for the occurrence of corruption.

The main goal of the article is determined as to study positive shifts in the system of economic governance which are aimed at eliminating conditions for the existence of political corruption and providing transparency of corresponding regulatory mechanisms as a prerequisite for the successful prevention of the appearance of corrupt acts.

We believe that in the broader sense in the system of state government, it is important not only assessments of the effectiveness of the counteraction in this area but also the ability to protect the relevant reforms from active attempts to examine existing achievements and to directly or indirectly slow down the country's anticorruption progress.

Due to objective reasons, we did not seek to analyse all possible corruption schemes (participants, volumes, instruments) and the effectiveness of the anti-corruption system being created today. Outside of this study, many questions remain regarding the SFS and customs reform, judicial reform, gas sector and public procurement reform, as well as issues of radical institutional changes and the definition of economic schemes for corruption mechanisms. These issues require a special analysis due to objective reasons: size and format of research. Undoubtedly, there is a problem of availability of the data necessary for the analysis and the reliability of the available information.

The need for international cooperation and application of progressive foreign experience in preventing corruption is reflected in the United Nations Convention against Corruption, which specifies that corruption is no longer a local problem and has transformed into transnational phenomenon that influences society and economies of all countries, which predetermines primary importance of international cooperation in the field of counteracting and controlling corruption (United Nations Convention against Corruption, 2003).

Active cooperation in the sphere of anti-corruption policy is carried out by European institutions. First of all, it concerns the Council of Europe. The approach of this organization to the fight against corruption has three interrelated aspects: development of pan-European norms and standards, control over their observance, as well as the provision of technical assistance to the states and regions (Letter from the Ministry of Justice, 2011).

Traditionally, the issue of preventing corruption occupies one of the prominent places in the policy of European states. It is obvious that organizational and legal forms and methods of its implementation vary since each of the states has its own specifics. For example, the fight against corruption in Germany is based on the task of destroying the material, first of all, the financial

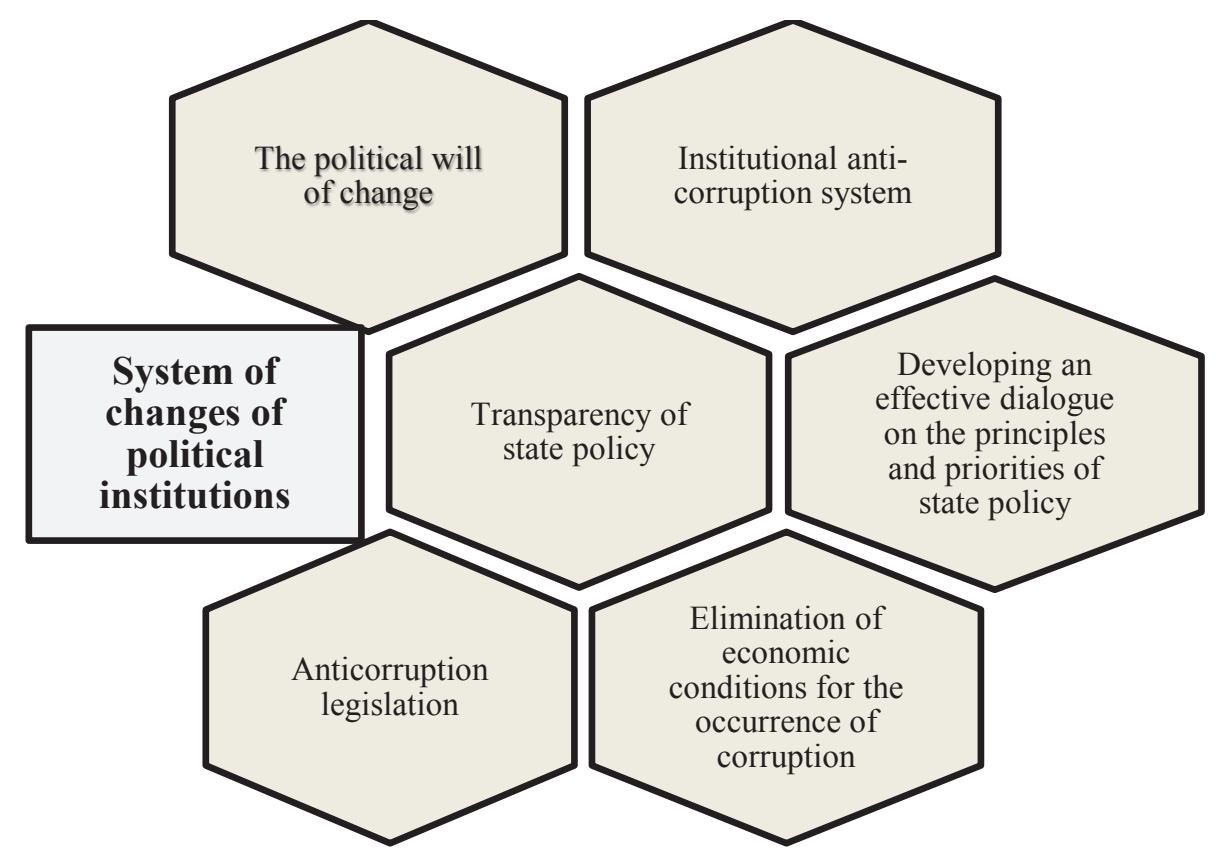

Figure 1. Components of reforming the anti-corruption system

Source: formed on the basis of Ukraine Against Corruption (2018) 
base of corruption. The overall strategy of the German government in the field of prevention of corruption is to eliminate, as a result of legislative, organizational, personnel, and other measures, the misuse by civil servants of their official position. The regulatory framework is maximally improved. An effective tool is the creation of a registry of corrupt firms. Its essence lies in the fact that the company included in such a register is deprived of the right to perform any government orders and becomes the object of more attention on the part of law enforcement authorities. However, in Germany, first of all, there are attempts to end corruption in the minds of members of society (Popok, Reshota, 2013).

The development of a comprehensive policy aimed at preventing corruption in Poland began under the powerful influence of the EU. In May 2000, Vice Prime Minister of Poland L. Balcerowicz initiated the formation of a working group at the Economic Committee of the Council of Ministers, whose purpose was to prepare a report on the main sources (factors) of the spread of corruption and an action plan for its elimination. The group included ministers of key departments and representatives of government institutions, experts of the World Bank, the Institute of Public Affairs under the Anti-Corruption Program (Stefan Batory Foundation) (Korupcja a polityka antykorupcyjna, 2011). Since the adoption of the Anti-Corruption Strategy in 2002, Poland has adopted a large number of laws and regulations, optimized administrative structures, which not only increased their effectiveness but also became a mechanism for preventing corruption (the simplicity of many procedures actually deprived officials of the tools that could be used to claim bribes). At the same time, the philosophy of functioning of administrative structures is changed towards increasing responsibility for providing public services. Policy of preventing and fighting corruption in Poland implements a wide range of disciplinary and criminal measures (strengthening criminal and administrative legislation in the fight against corruption; establishment of specialized institutions; creation of special mechanisms of external and internal control over activities within the public administration authorities; effective judicial system), preventive measures (mechanism that simplify various procedures where subjects are, on the one hand, a citizen, on the other - public bodies; elimination of gaps in legislation that allowed for corruption abuses; clearly defined codes of conduct of public officials and concrete steps of action in certain situations; provision of access to public information and e-governance; education of the population and officials; support of non-governmental organizations, etc.) (Paweł Dziekański, 2017; Rybak, 2011).

In Central Europe, considerable attention is being paid to the adoption of detailed anti-corruption laws aimed at criminalizing the full range of acts related to bribery. Most countries have also introduced anti-corruption programs at the national level. The answer to the fight against corruption in many countries was the increase in the number of anti-corruption legislative acts. In particular, the fight against corruption as one of the main priorities of the Government of the Czech Republic is based on an appropriate strategy. It is aimed at reducing the level of corruption, gradual implementation of measures on the basis of the balance of prevention and suppression of corruption and transparency of this process. When developing the strategy, projects of Transparency in Government Procurement Platform were used (Rybak, 2011).

\section{Results and discussion}

Corruption in Ukraine - not just socio-economic phenomenon that is present in varying degrees today in many countries of the world. It is a system of relations that penetrated all spheres of society's life. Before revolutionary events in 2014, despite loud political statements and some anti-corruption decisions, corruption only intensified, as reflected in relevant international rankings (Table 1 ).

Data for calculations are obtained from the following sources: World Economic Forum; Global Insight Country Risk Ratings; Bertelsmann Foundation Transformation Index; IMD World Competitiveness Center Yearbook; World Justice Project Rule of Law IndexExpertSurvey; PoliticalRiskServices International Country Risk Guide; Varieties of Democracy (V-Dem); Economist Intelligence Unit Country Risk Service; Freedom House Nations in Transit (Ukraine Against Corruption, 2018).

According to data given in Table 1, on the eve of the Revolution of Dignity, Ukraine was perceived as one of the most corrupt countries in the world, occupying 144th place (the higher the score in points and, consequently, the smaller the place of the country, the less corrupt it is considered and vice versa) by this indicator in the world. A similar situation is observed in relation to other indicators, on the basis of which the Corruption Perceptions Index is calculated.

Table 1

The Corruption Perceptions Index by Transparency International and data sources to calculate it, 2012-2017

\begin{tabular}{|l|c|c|c|c|c|c|}
\hline \multicolumn{1}{|c|}{ Year } & 2012 & 2013 & 2014 & 2015 & 2016 & 2017 \\
\hline Place in rating & $144-$ & $144+$ & $142+$ & $130+$ & $131-$ & $130+$ \\
\hline $\begin{array}{l}\text { Corruption Perceptions Index: } \\
\text { general score (conditional points) }\end{array}$ & $26-3$ & $25-1$ & $26+1$ & $27+1$ & $29+1$ & $30+1$ \\
\hline
\end{tabular}

Source: formed on the basis: International Monetary Fund (2017). Retrieved from: https://www.transparency.org/research/cpi/overview) 
Table 2

The level of the shadow economy in Ukraine to GDP

\begin{tabular}{|c|c|c|}
\hline Year & $\begin{array}{c}\text { The level of shadow economy, } \\
\text { \% to Ukraine's official GDP }\end{array}$ & $\begin{array}{c}\text { Change in the volume of Ukraine's real GDP, } \\
\text { \% to the respective period of the previous year }\end{array}$ \\
\hline 2010 & 38 & 4,1 \\
\hline 2011 & 34 & 5,5 \\
\hline 2012 & 34 & 0,2 \\
\hline 2013 & 35 & 0,0 \\
\hline 2014 & 43 & $-6,6$ \\
\hline 2015 & 40 & $-9,8$ \\
\hline 2016 & 35 & 2,4 \\
\hline 2017 & 33 & 2,3 \\
\hline
\end{tabular}

Source: formed on the basis of International Monetary Fund (2017). Calculations of the MEDT of Ukraine (2010-2017).

Retrieved from: http://www.me.gov.ua/Documents/List?lang=uk-UA@ 'id=e384c5a7-6533-4ab6-b56f-50e5243eb15a\&'tas=TendentsiiTinovoiEkonomiki

In economic terms, corruption in Ukraine has become a serious obstacle to its economic development. Without its elimination, Ukraine will simply not be able to overcome the historical lag behind developed countries and regions of the world. If Ukraine cannot reduce corruption, GDP per capita in 2040 will be only $30 \%$ of the same indicator in the EU EC (Ukraine Against Corruption, 2018).

If the level of corruption in Ukraine will reduce to the highest corruption level among EU member states, Ukrainian GDP per capita will be $40 \%$ of the EU average indicator. If the level of corruption in Ukraine will be the same as the EU average, GDP per capita in 2040 will exceed $50 \%$ of the EU average, and this gap will be reduced rapidly in the future. Ukraine is traditionally characterized by a high level of shadow economy (Table 2). In 2014, the level of shadow economy was $43 \%$ in relation to official GDP (Calculations of the Ukrainian Ministry of Finance, 2010-2017).

It is clear that, under equal conditions, the shadow economy is both a source and a result of corruption. Although the size of the shadow economy is gradually diminishing since 2015, its level remains large, with all the relevant political and economic consequences and corrupt content. At the same time, it should be remembered that the high level of the shadow economy is also explained by the fact that the shadow economy itself is one of the business strategies that allows it to mitigate the impact of the economic crisis (and therefore, naturally, its level has increased during the crisis).

It should be noted separately that Ukraine traditionally had a high level of tolerance of society to petty corruption. This, in particular, was reflected in the widespread belief that the government simply does not work without corruption. For the sake of justice, we would point out that such an opinion had some support among experts dealing with economic development. An assessment of the effectiveness of measures aimed at overcoming corruption is a rather complicated problem. In order to make an assessment, we based our study on the approach that can be described as follows:
1. It is impossible to absolutely accurately determine the real volume of corruption (and, therefore, it is impossible to accurately determine the economic losses of society) since any assessment of this phenomenon depends on the methodology and the initial assumptions of the analysis. This is also true for the assessment of the economic effect of anti-corruption measures. Under such conditions when discussing the scale of the relevant phenomena, one way or another there is the question of their underestimation or overestimation, moreover, the affirmation of the correctness or incorrectness of such assessments is mostly subjective.

2. In technical terms, the effectiveness of the fight against corruption can be assessed using several indicators, each of which has its own specific scope of application, summarized indicators are presented in Figure 2.

It is obvious that these indicators are interrelated; however, at the same time, each group has its own scope of application. Note that traditionally in the discussions on the issues of anti-corruption policy, their participants operate precisely with the indicators of the second and third groups, or they contrast indicators of these groups against indicators of the first group. In our opinion, this does not allow adequately assessing the state of affairs in the field of fighting corruption.

3. In one form or another, corruption is present in many spheres of life in Ukraine. Of course, without a detailed "sectoral" analysis of corruption and an objective assessment of the effectiveness of the relevant anti-corruption measures in such spheres as education, medicine, healthcare, military procurement, etc., it is difficult to talk about the real pace and extent of anticorruption progress of the country. Herewith, it should be considered that society is extremely sensitive to the processes taking place in these areas, which objectively complicates discussion on the efficiency/inefficiency of the relevant anti-corruption measures.

Undoubtedly, the solution to these issues is formed by a complex multi-faceted mechanism, within this work we propose to consider the following classification of anti-corruption measures, which is presented in Table 3. 


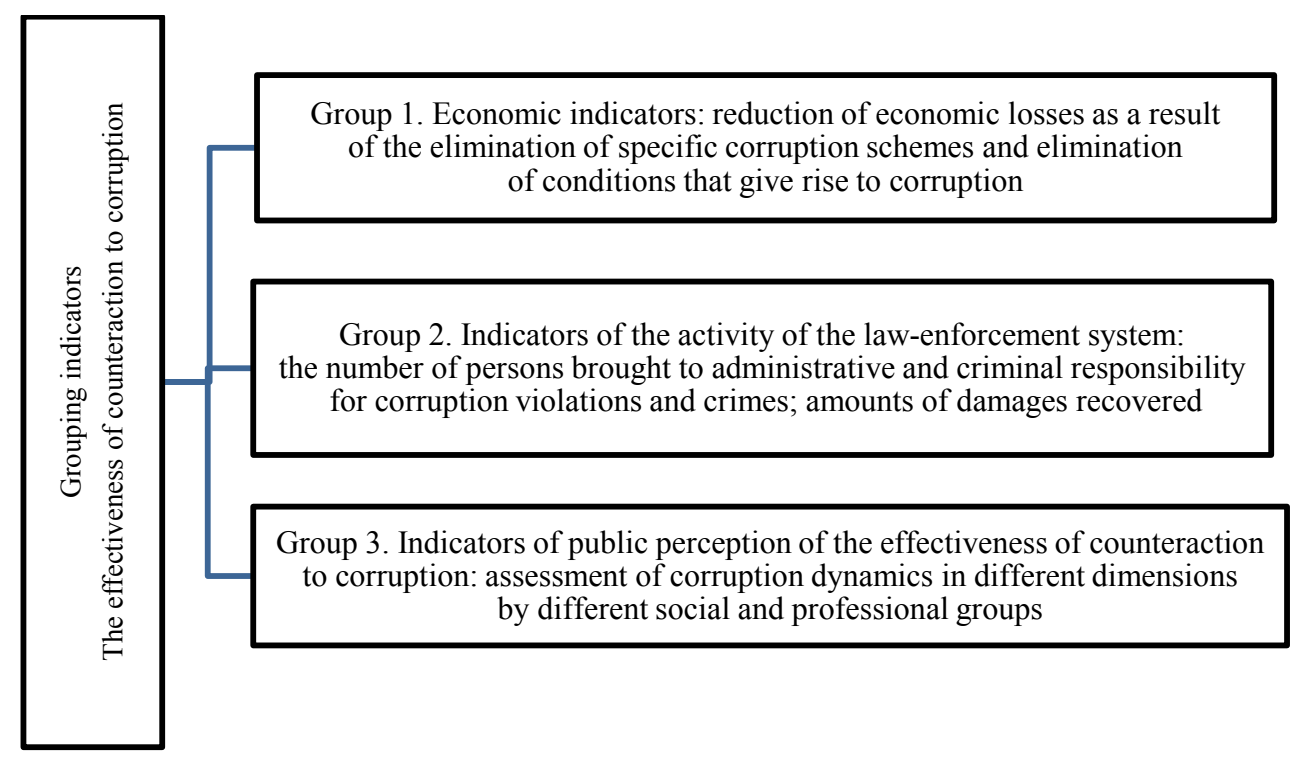

Figure 2. Summarized group of indicators to measure the effectiveness of the fight against corruption Source: summarized by the authors based on: Ukraine Against Corruption (2018)

In general, it should be noted that the purpose of all these measures is to build a system of management of the relevant spheres on the basis of economic expediency and transparency and ensure their functioning in full compliance with the public interest in the strict sense of the term.

The formation of the national legal framework for fighting corruption is based on the relevant international anti-corruption conventions, other international legal documents containing clear internationally accepted definitions, which acts should be considered corrupt offenses, which entities should be responsible for them, which sanctions and other criminal measures (such as special confiscation and special measures for legal entities) should be established, etc.

Confirming its European integration aspirations, over the last decade Ukraine has ratified the Criminal Law Convention on Corruption of the Council of Europe as of January 27, 1999 (Law № 252-V as of 18.10.2006), the Additional Protocol to this Convention dated May 15, 2003 (Law № 253-V as of 18.10.2006), the Civil Law Convention on Corruption of the Council of Europe as of November 4, 1999 (Law № 2476-IV as of 16.03.2005), the United Nations Convention against Corruption as of December 11, 2003 (Law № 251-V as of 18.10.2006), the Council of Europe Convention on Laundering, Search, Seizure and Confiscation of the Proceeds from Crime and on the Financing of Terrorism (Law № 2698-VI as of 17.11.2010), the United Nations Convention against Transnational Organized Crime as of November 15, 2000 (Law № 1433-IV as of 04.02.2004), and the Council of Europe Convention on the Manipulation of Sports Competitions as of September 18, 2014 (Law № 1752-VIII as of 16.11.2016). By ratifying the Council of
Europe Civil Law Convention on Corruption, Ukraine has joined the Group of States against Corruption (GRECO).

On the basis of anti-corruption standards determined in these and other international documents, numerous laws were adopted:

a) of general nature on responsibility for corruption offenses and offenses related to corruption: "On the Principles of State Anti-Corruption Policy in Ukraine (the Anti-Corruption Strategy) for 2014-2017", "On Corruption Prevention", "On Purification of Government”, separate provisions of Criminal, Criminal Procedure, Civil, Civil Procedure Codes of Ukraine, Code of Ukraine on Administrative Offences, and Code of Administrative Procedure of Ukraine;

b) on the activities of specialized anti-corruption bodies: "On the National Anti-Corruption Bureau of Ukraine", "On the Prosecutor's Office", "On the National Police", "On the State Bureau of Investigation", "On the Security Service of Ukraine”, "On Operational Search Activities", "On Organization-Legal Bases of Fight Against Organized Crime”;

c) on ethical rules, anti-corruption restrictions and prohibitions for some officials, and on political corruption prevention: "On Civil Service”, "On Judicial System and Status of Judges", "On Political Parties in Ukraine", "On Election of the President of Ukraine", "On Elections of People's Deputies of Ukraine", separate provisions of the Labour Code of Ukraine, etc.;

d) on corruption prevention in the economy and sports: "On Public Procurement", "On Economic Competition Protection", separate provisions of the Commercial and Commercial Procedure Codes of Ukraine, "On Prevention of the Impact of Corruption Offences on the Outcomes of Sports Competition" and others; 
Table 3

Anticorruption measures: key characteristics and interconnections

\begin{tabular}{|c|c|c|}
\hline $\begin{array}{c}\text { The purpose } \\
\text { of anti-corruption measures }\end{array}$ & Measure application procedure & Anticorruption effect \\
\hline Creation of a full-fledged gas market & $\begin{array}{l}\text { Aligning gas prices for different categories } \\
\text { of consumers. Termination of joint activity } \\
\text { agreements. Revision of contracts for gas } \\
\text { supplies from Russia. Alternative channels } \\
\text { of gas supply to Ukraine. Reform of NJSC } \\
\text { Naftogaz's corporate governance. }\end{array}$ & $\begin{array}{l}\text { Reducing opportunities for price arbitrage. } \\
\text { Depolitization of gas relations with Russia. Reducing } \\
\text { opportunities for political corruption, including by } \\
\text { eliminating the intermediary (RosUkrEnergo). } \\
\text { Minimizing the opportunities to obtain corrupt } \\
\text { rents due to the presence of a monopoly supplier. } \\
\text { Strengthening the company's resilience to external } \\
\text { political influences, which ultimately lead to the } \\
\text { appearance of various corruption schemes. }\end{array}$ \\
\hline $\begin{array}{l}\text { Fight against tax pits and conversion } \\
\text { platforms }\end{array}$ & $\begin{array}{l}\text { Introduction of the system of electronic } \\
\text { administration of VAT. Implementation } \\
\text { of the risk monitoring system in the VAT } \\
\text { administration system. Automatic refund of VAT }\end{array}$ & $\begin{array}{l}\text { Unshadowing financial flows and minimizing a } \\
\text { scheme tax credit }\end{array}$ \\
\hline $\begin{array}{l}\text { Creating a transparent, open, and } \\
\text { competitive public procurement market }\end{array}$ & $\begin{array}{l}\text { Implementation of ProZorro's public } \\
\text { procurement system. Creating a system for } \\
\text { monitoring public procurement by the State } \\
\text { Audit Service of Ukraine. } \\
\text { Creation of a special monitoring portal } \\
\text { Dozorro. Purchase of medicines by IO. }\end{array}$ & $\begin{array}{l}\text { Ensuring direct open competition between suppliers } \\
\text { Identification of risks of abuses in public } \\
\text { procurement and their minimization at all stages } \\
\text { of the procurement process. } \\
\text { Public oversight of public procurement by all } \\
\text { stakeholders. }\end{array}$ \\
\hline $\begin{array}{l}\text { The opening of state registers and other } \\
\text { data related to public administration and } \\
\text { ensuring equal access to it for all parties } \\
\text { concerned }\end{array}$ & $\begin{array}{l}\text { Determination of data sets to be made public. } \\
\text { Creation of the Unified State Open Data Portal } \\
\text { and relevant specialized open data portals. } \\
\text { Creation of the Unified State Register } \\
\text { of Declarations of Persons Authorized } \\
\text { to Perform State or Local Government } \\
\text { Functions. }\end{array}$ & $\begin{array}{l}\text { Minimizing the conditions for manipulating and } \\
\text { abusing relevant data } \\
\text { Expanding the possibilities of public control over } \\
\text { the activity of the authorities } \\
\text { Ensuring equal access to relevant data for all } \\
\text { stakeholders. } \\
\text { Prevention of abuse by officials. }\end{array}$ \\
\hline $\begin{array}{l}\text { Eliminating excessive administrative } \\
\text { control of entrepreneurial activity by } \\
\text { simplifying the relevant procedures }\end{array}$ & $\begin{array}{l}\text { Deregulation. Provision of administrative } \\
\text { services in electronic format. } \\
\text { Simplifying the registration of medicines of } \\
\text { foreign origin. }\end{array}$ & $\begin{array}{l}\text { Reducing regulatory costs for business. Automatic } \\
\text { provision of administrative services without the } \\
\text { "mediation" of the authorized representative of } \\
\text { the state. Shortening the procedure for bringing } \\
\text { foreign drugs to the Ukrainian market. }\end{array}$ \\
\hline $\begin{array}{l}\text { Prevention of political interference and } \\
\text { corruption, delimitation of regulator } \\
\text { and owner functions, the introduction } \\
\text { of internationally recognized corporate } \\
\text { governance standards }\end{array}$ & Corporate governance reform & $\begin{array}{l}\text { Reduction of intra-corporative corruption } \\
\text { space. Strengthening the company's resilience } \\
\text { to external political influences, which ultimately } \\
\text { lead to the appearance of various corruption } \\
\text { schemes. }\end{array}$ \\
\hline $\begin{array}{l}\text { Clearing the banking sector from } \\
\text { institutions that are actually an } \\
\text { instrument for implementing various } \\
\text { schemes of abuse by their owners. }\end{array}$ & $\begin{array}{l}\text { Introduction of identification of ultimate } \\
\text { beneficiaries. Resolving the issue of lending } \\
\text { to related parties. }\end{array}$ & $\begin{array}{l}\text { Transparency of the ownership structure of banks } \\
\text { as a factor of increasing the efficiency of banking } \\
\text { supervision. Prevention of the appearance of } \\
\text { various schemes of abuse by the owners of banks. }\end{array}$ \\
\hline
\end{tabular}

Source: formed based on Ukraine Against Corruption (2018); Calculations of the Ukrainian Ministry of Finance (2010-2017); International Monetary Fund (2017)

e) on access to information: some provisions in the Civil, Commercial, Budget, and Land Codes of Ukraine, laws "On the National Agency of Ukraine on Detection, Search and Management of Assets Obtained through Corruption and Other Crimes", "On the State Registration of Legal Entities, Sole Traders and Public and Civil Organizations", "On State Registration of Property Rights to Real Estate and their Encumbrances", "On Road Traffic", "On the State Land Cadastre", "On Television and Radio Broadcasting", "On the Transparent Use of Public Funds", "On Information", “On Access to Public Information”, and "On Access to Court Decisions" etc.
Based on the above-listed laws, dozens of acts of secondary legislation were adopted by the Cabinet of Ministers of Ukraine, National Agency on Corruption Prevention, Ministry of Justice of Ukraine and others. All this enables us to state that, in general, a legislative framework for corruption prevention has been created in Ukraine. Yet, in spite of the fact that many laws were passed, 35\% of 200 anti-corruption measures, which, according to the State Program for Anticorruption Strategy Implementation were supposed to be implemented by the end of 2017 , have not been implemented. There is no Anticorruption Strategy or 
its State Implementation Program for 2018 and beyond. Also not passed are many important anti-corruption laws, which could have helped the further recovery of Ukraine's economy, finances, social protection systems etc. These include laws on transparency with respect to allocation of budget expenditures and usage of natural resources, administrative procedures, lobbying (Draft Law "On Ensuring Transparency and Legality of Communication with the Authorities”, 2017), integrity checks, protection of whistle-blowers, establishment of the office of Business Ombudsman (The Draft Law "On the Establishment of a Business Ombudsman”, 2016) etc.

\section{Conclusions}

For successful application of the experience of EU countries when developing effective anti-corruption policy in Ukraine, it is necessary: firstly, determine and implement in Ukrainian legislation relevant international legal rules of state, regional, and local nature; secondly, given the successful experience of certain countries, identify a complex of most important for Ukraine factors aimed at providing effectiveness of state policy of preventing corruption, structure them based on principles of priority and the most functionality in order to create a model optimal for Ukrainian conditions; thirdly, develop and form for this model proper institutional support of regulatory character that would harmoniously combine state, regional, and local levels of public administration.

The paper determines "direct" anti-corruption effects of corresponding changes in economic governance.
It is obvious that direct effects can be levelled by corruption risks in related spheres. So, the delegation of certain powers and financial resources to the local level in the process of decentralization objectively restricts corruption space in the "centre-regions" relations in terms of the distribution and use of financial resources, however, without effective anti-corruption system at the local level, the anti-corruption effect of decentralization will be less than expected.

The system of corruption prevention includes rules of anti-corruption behaviour general for all subjects under the anti-corruption legislation and special ones for separate groups of such subjects (deputies, public servants, judges, workers of law enforcement authorities, heads of state enterprises and so on) or separate spheres, and also means of control, monitoring, and other means for ensuring compliance with the specified rules and provides for the possibility to change them if indicated by corresponding indicators.

In order to overcome mass violations of anticorruption norms and rules, it is needed to implement a whole range of measures to criminalize corruption, that is, to establish criminal responsibility for corruption offenses and corruption-related offenses and create a law enforcement system capable of effectively counteracting the corruption actions that we have identified in the study.

As further research directions, we consider appropriate to investigate in more detail some spheres specified by us as strategically important directions of reform for Ukraine.

\section{References:}

About twenty principles of struggle against corruption (1997). Resolution (97) 24 of the Committee of Ministers of the Council of Europe. Adopted by the Committee of Ministers on November 6, 1997 at the 101st session. Retrieved from: http://zakon2.rada.gov.ua/laws/show/994_845

Calculations of the Ukrainian Ministry of Finance (2010-2017). Retrieved from: http://www.me.gov.ua/ Documents / List?lang=uk-UA\&id=e384c5a7-6533-4ab6-b56f-50e5243eb 15a\&tas=TendentsiiTinovoi Ekonomiki

Draft Law "On Ensuring Transparency and Legality of Communication with the Authorities" (Reg. No. 7129 dated September 20, 2017) on September 22, 2017 was given for familiarization. Retrieved from: http://w1.c1.rada.gov.ua/ pls/zweb2/webproc4_1?pf3511=58980

Decree of the President of Ukraine "On the Establishment of the National Anti-Corruption Bureau of Ukraine" No. 217 / 2015 dated April 16, 2015. Retrieved from: https://zakon2.rada.gov.ua/laws/show/217/2015

European governance. [White book]. Retrieved from: http://www.upi.org.ua

International Monetary Fund (2017). International Monetary Fund. IMF Country Report No. 17/84. Ukraine, Selected Issues. March 7.

Korupcja a polityka antykorupcyjna (2011). Raporty krajowe. Retrieved from: http://www.batory.org.pl/ftp/ program/przeciworupcji/publikacje/inne-publikacje/korupcja_i_polityka_antykorupcyj na.pdf

Kyrylenko, O. (2015). Detsentralizatsiya byudzhetnoyi systemy Ukrayiny $\bar{v}$ umovakh formuvannya vidkrytoho suspilstva [Decentralization of the budgetary system of Ukraine in the conditions of formation of an open society]. Ternopil: Economic Thought.

Letter from the Ministry of Justice (2011). Ukraine's participation in international cooperation in the field of prevention and counteraction to corruption. Letter dated June 22, 2011 from the Ministry of Justice of Ukraine. Retrieved from: http://zakon2.rada.gov.ua/laws/show/n0042323-11

Martynyuk, O. (2015). Formation of the imperatives of sustainable development for structural transformations of the economy. Bulletin of the Odessa National University. Series: Economics, 20(6), 44-48. 
Popok, A., Reshota, V. (2013). State policy on the prevention and counteraction of corruption in the Czech Republic and Slovakia: experience for Ukraine. Retrieved from: http://lvivacademy.com/visnikl2/zmist.html. Paweł Dziekański (2017). Economic effectiveness of the activities of local self-government units in the light of the municipality financial resources. Scientific bulletin of Polissia, 3(11). doi: 10.25140/2410-9576-2017-1-3(11)-76-82/ Rybak, A. (2011). State Policies to Fight Corruption in Poland: Regulatory / Institutional Aspect. Gilea: Scientific Bulletin. Collection of scientific works. Kyiv: VIR UAN.

Stepanova, A. (2015). Byudzhetne rehulyuvannya v umovakh instytutsiynykh peretvoren [Budgetary regulation in the context of institutional reforms]. Molodyy vchenyy [Young Scientist], 2(17), 25-28.

Ukraine Against Corruption (2018). Ukraine Against Corruption: Economic Front. Economic evaluation of anticorruption measures in 2014-2018. Dnipro: T.K.

United Nations Convention against Corruption (2003). Retrieved from: http://zakon2.rada.gov.ua/laws/ show $/ 995$ ci6

The Draft Law "On the Establishment of a Business Ombudsman" (Reg. No. 4591 dated May 5, 2016) was adopted as a basis on May 31, 2016. Retrieved from: http://w1.c1.rada.gov.ua/pls/zweb2/webproc4_1?pf3511=58980

Shevchuk, B. (2012). European principles of good governance and reform of the executive power system in Ukraine. Democratic Governance, 9. Retrieved from: http://www.lvivacademy.com

Yameletsky, O. (2012). Implementation of the principles of "proper" governance as a factor in activating political participation. Retrieved from: http://archive.nbuv.gov.ua 